\title{
IRREGULAR LEVIES AND THE IMPACT OF THE ROMAN ARMY IN EGYPT
}

\author{
Colin Adams
}

There has been considerable debate on the economic impact of the army on Roman provinces. Clearly some provinces were affected more than others; there can be no question that there was a typical Roman province. Some were wealthier than others in agricultural and other resources, some more populous than others; so it is very difficult to develop a universal picture of economic impact. It is hardly credible that the cost of the army at any time in the Roman period was spread evenly throughout the empire. Any attempt to quantify the impact of the army on provinces faces a further problem: lack of evidence. However, the papyri of Egypt provide enough information for some notion of the scale of impact to be developed, even if it falls short of providing a definitive answer.

It has been suggested that the economic impact of the army in Egypt was small. This is based on a comparison between the total estimated tax revenues for the province and the total cost of paying soldiers based there: the cost of the army, it is suggested, represented about $2 \%$ of revenue. ${ }^{1}$ Even if these estimates are low (for they are incomplete and do not reckon the total production of the province), the cost of the army could not have been more than a third or a quarter of the tax revenues, and less than $10 \%$ of the total surplus production. ${ }^{2}$ The size of the army in relation to the population of Egypt was such that this can hardly have represented a significant imposition, especially if demands were spread equitably. While certainly useful in establishing a

${ }^{1}$ Gf. J.M. Carrié, 'Le rôle économique de l'armée dans l'Egypte romaine', in C. Nicolet and H. van Effenterre, eds., Armées et fiscalité dans le monde antique (Colloques nationaux du CNRS 963) (Paris 1977), 373-393; R. Alston, Soldier and Society in Roman Egypt (London/New York 1995), 112-115.

2 See R.S. Bagnall, Egypt in Late Antiquity (Princeton 1993), 172. It is not necessary here to provide, even if it were possible, a break down of figures, but consider that the estimated requirements for the $\mathrm{AD} 23$ garrison of 16,000 men (c. 192,000 artabas) is minute in comparison to the estimated annual yield of grain in Egypt of 81 million artabas. But of course this was only part of the cost. 
notion of scale, these estimates obscure a number of important points. First, the army's needs may have been fairly constant in every year (the same number of troops needed the same pay and supply of food and fodder for animals), but not every year was as abundant in agricultural produce as another. The effects of a poor harvest were not felt equally by different regions (nomes), which might directly affect the equity of tax imposition. Second, there was a range of irregular impositions not allowed for in these calculations. Third, no account is taken of the huge imposition in terms of bureaucracy (which in itself could have a significant economic impact in a number of ways) forced onto the local population, not just by regular taxation and military supply, but perhaps especially by these irregular levies. ${ }^{3}$ It is all too easy to downplay the significance of these, assuming that they were singular responses to particular crises or circumstances, but they happen often, and were probably more regular than we might think. One, at least, happened every year, the conventus of the prefect: a feature of all provinces. Others included tours of officials, such as epistrategoi, and soldiers in the normal course of their duties, and, of course, imperial visits. ${ }^{4}$ While I do not want to overplay their significance, it must be said that they represented a very real imposition at a local level on individuals, which must have been at once highly tangible, a considerable economic imposition on the individual, and an additional administrative burden on an already over-burdened system.

Another burden on Egypt, easily overlooked, but which was significant, was its expected contribution to imperial campaigns elsewhere, for which we have some evidence. ${ }^{5}$ Again, while we should not stress the regularity of these, they must have represented a significant burden both economically and bureaucratically, even assuming, as is likely, that the same administrative systems were used. A recently published papyrus from the collection of Yale University amply displays this in relation to Caracalla's campaign in Syria. ${ }^{6}$ This preserves a register of

\footnotetext{
${ }^{3}$ On bureaucracy and military supply, see C.E.P. Adams, 'Supplying the Roman Army: Bureaucracy in Roman Egypt', in A. Goldsworthy and I. Haynes, eds., The Roman Army as a Community. Journal of Roman Archaeology Supplementary Series 34 (Portsmouth, R.I. 1999), 119-126.

${ }^{4}$ For journeys by epistrategoi, see J.D. Thomas, The Epistrategos in Ptolemaic and Roman Egypt: Part 2: The Roman Epistrategos (Opladen 1982), 57-64.

P. Oxy. 3090-3091 (AD 216-17), see also BGU 266 = W. Chr. 245 (AD 216-17), see also P. Got. 3; P. Stras. 245.

${ }^{6}$ P. Yale 137 (AD 215/6).
} 
payments in cash and kind made by individuals, and shows the real impact of such requisitions at a local level. To these foreign campaigns we must add local disturbances and incursions into Egypt, and supplies requisitioned for any imperial projects supported by soldiers such as mining and quarrying in the Eastern Desert.

There was a local impact to these exactions, and this is something, certainly with respect to the conventus, that became an annual burden for the same communities each year. There is some evidence from Egypt for the course of the conventus, and it is clear from similar evidence from Asia Minor, that governors undertook a set itinerary. What we would like to know is if the burden of providing for this and other irregular impositions was distributed equitably.

The subject of this essay is to consider some aspects of the impact of such impositions on the province of Egypt. The main source with which I am concerned is the first of two substantial papyri from the Chester Beatty library in Dublin, P. Panop. Beatty 1 and 2, which date from AD 298 and 300 respectively. Together these documents are among the longest papyri to survive from Egypt - having some 700 lines of text, preserving around 87 letters exchanged between officials in provincial government (and importantly communication with city authorities) and programmata, which provide important information about the dissemination of official decisions among the local population. ${ }^{7}$ What I want to do is to place this evidence into a wider context.

\footnotetext{
7 The texts have received little attention. The basic work on administrative structures in fourth century Egypt remains J. Lallemande, L'administration civile de l'Égypte de l'avènement de Dioclétien à la création du diocèse (284-382). Contribution à l'étude des rapports entre l'Égypte et l'Empire à la fin du III et au IV siècle (Brussels 1964), but was completed before the publication of the Panopolis papyri. The most recent book on Late Antique Egypt, Bagnall 1993, op. cit. (n. 2) is too wide in scope to consider the documents closely. R. Duncan-Jones, 'Pay and Numbers in Diocletian's Army', in Structure and Scale in the Roman Economy (Cambridge 1990), 105-117, tackles military pay and unit sizes in the light of a brief mention of the texts in a note of A.H.M. Jones, The Later Roman Empire 284-602, 2 vols (Oxford 1964), II 1257-9. More recently in a series of short articles, N. Lewis has considered points of detail: N. Lewis, 'In the world of P. Panop. Beatty,' Bulletin of the American Society of Papyrologists 28 (1991), 163-78; id., 'In the World of P. Panop. Beatty: Ship Repair,' Bulletin of the American Society of Papyrologists 38 (2001), 89-96; id., 'In the World of P. Panop. Beatty 1: 'An Army Marches on its Stomach,' Chronique d'Égypte 78 (2004), 221-228 (which considers the appointment of liturgists in detail). For a survey of broad themes, preliminary to a major study, see C.E.P. Adams, 'Transition and Change in Diocletian's Egypt: Province and Empire in the Late Third Century', in S. Swain and M. Edwards, eds., Approaching Late Antiquity: the Transformation from Early to Late Empire (Oxford 2004), 82-108.
} 
P. Panop. Beatty 1 preserves in remarkable detail a range of matters pertaining to the impending visit of Diocletian to Panopolis in the wake of the revolt of L. Domitius Domitianus in AD 297. ${ }^{\circ}$ In a letter of 13th September 298 (Thoth 16) from the strategos of the Panopolite nome to the president of the town council of Panopolis, Aurelius Plutogenes alias Rhodinus, he complains that despite two instructions "with regard to the supplies of the annona ordered to be stored up in various places in preparation for the auspiciously impending visit of our ruler, the Emperor Diocletian, the Senior Augustus", the president has not yet appointed liturgists to oversee the process and is now reminded for the third time. ${ }^{9} \mathrm{~A}$ day later the strategos wrote again, ${ }^{10}$ and a day later (Thoth 18) sent a letter of complaint to the Procurator of the Lower Thebaid about the inefficiency and obstinance of Aurelius Plutogenes, who had refused to appoint a surveyor to oversee the requisition of ships for the Treasury. ${ }^{11}$

Three points follow. First, the urgency and frequency of the communication - what real point is there in writing a follow up letter the next day and a letter of complaint to the procurator another day later? Why does the strategos put so much pressure on the president? It is clear that both the strategos and president are resident in Panopolis, which explains the verbal commands mentioned, and the delivery by hand of the letters. Second, inefficiency can perhaps be put down to more than just a general lack of interest or concern over the burdens imposed; first, the bewildering range of liturgists needed, and second the unenviable position in which the president found himself, in which he had to play a two-sided game of pleasing the strategos and procurator, while not alienating his fellow citizens in the process. Such a conflict of interests is part and parcel of the dynamics of administration illustrated by the Beatty texts. A common misconception about Roman Egypt is that the over-bearing bureaucracy meant that things happened - more often than not they didn't. And third, in his final letter, the strategos invokes the name and authority of his superior, Aurelius Isidoros, the Procurator of the Lower Thebaid, and adds a warning: "now again I hasten to enjoin you even so to select the persons aforesaid, in order that you

\footnotetext{
8 See Lewis 2004, op. cit. (n. 7).

9 P. Panop. Beatty 1. ll. 53-9 (trans. Skeat).

10 P. Panop. Beatty 1. ll. 109-19, see Lewis 2004, op. cit. (n. 7), 224.

11 P. Panop. Beatty 1. ll. 167-179.
} 
may avoid placing yourself and me in jeopardy". This shows that the strategos ultimately has little influence or power over the president of the council, that he protects himself from reproach from his superiors by writing a letter of complaint to the procurator, thus covering his back and passing the buck. Officials had very little sanction to carry out threats, which became idle, and this was well-known. This is perhaps one reason for the volume and regularity of correspondence, and is one sign of a authoritarian regime struggling to maintain control.

The papyrus furnishes important information on the liturgists and their roles. ${ }^{12}$ Apaitatai ('Collectors'), Apodektai ('Receivers') and Diadotai ('Distributors'), and Epimeletai ('Overseers'), who probably had a supervisory role and who kept accounts, were appointed in pairs. A wide range of commodities was required - meat, chaff, wine, bread, animals, ${ }^{13}$ vegetables, sour wine (oxos), lentils, barley and bedding, and we have the general term annona - each had its own collectors, receivers, distributors and overseers. The organisation is complicated; it suffices to say here that 60 liturgists were appointed throughout the 6 toparchies. These were administrative divisions of the Panopolite nome, and each of these had liturgists responsible for each commodity. It is interesting that the president appoints liturgists in this way against the explicit instructions of the procurator that they should be appointed with responsibility for the whole nome, rather than individual toparchies. It seems clear that the president prefers to ignore attempts to interfere with established administrative practice, to make it more centralised. A letter sent from the strategos to the procurator, points this out, and shows that the procurator ordered that all liturgists should work in concert for the nome as a whole. However, this is ignored, and this is interesting in itself, for it shows that the strategos and indeed even the procurator had no real sanction over local authorities: his position was ultimately ineffectual. ${ }^{14}$ It also suggests less interest on the part of the president in the equitable distribution of the burden, as this would cause additional administrative pressure (rather than merely using the normal procedures). Another possibility, and one that occasionally crops up in our evidence is that

12 At P. Panop. Beatty p. 124, Skeat presents a table summarizing this, which is replicated by Lewis 2004, op. cit. (n. 7), 226-227. Lewis discusses the various liturgists and their functions.

${ }^{13}$ It is likely that these were for sacrifice: Lewis 2004, op. cit. (n. 7), 227.

14 See Adams 2004, op. cit. (n. 3). 
the requirements of the state were misunderstood or misinterpreted by local officials in the town councils. Sometimes this might have been deliberate, others genuine. ${ }^{15}$

Several details are absent. The first, and most important of these, is the quantity required of each commodity. As so often is the case, the most important information for us, which might enable us to estimate the size of Diocletian's entourage is missing. There are a few tantalising details - 1,000 artabas of lentils and 10,000 sextarii of sour wine. 800 artabas of wheat, as annona for the soldiers stationed at Panopolis (and those in transit), were to be provided from two toparchies (again suggesting inequitable distribution), but this is not quite enough for us to establish the size of Diocletian's party. ${ }^{16}$ All that can be said is that, based on the figure of 10,000 sextarii of oxos mentioned above, and the fact that a normal daily ration for a soldier was 2 sextarii, and we assume that Diocletian must have been in Panopolis for one day or more, his military party cannot have been larger than 5000 men, and this figure gets proportionally smaller the longer he stayed (and, of course, we do not know that). ${ }^{17}$ If we assume that the size was 5000 for the sake of argument, and accept that Diocletian was in Egypt for over a year, this alone represents over a $50 \%$ increase in the number of soldiers in the province, with a concomitant increase in the cost to supply them. We must also consider that he probably did not travel with his full complement, and the remainder of his expeditionary force must have been stationed elsewhere with similar impact.

We have some details preserved of supplies set aside for the garrisons at the local forts at Psinabla and Thmoö (animal skins for the former, two months rations of 2610 Italic modii of barley for horses and 128 9/24 artabas and 100 artabas of wheat). These figures were studied by Duncan-Jones, who suggested that the auxiliary unit here, at least in $\mathrm{AD} 298$, probably numbered 116 (based on a ration of 4 choinikes of barley per horse per day for two months). Rations in wheat fall short of average, but soldiers received cash as well. ${ }^{18}$

15 An example of this might be seen in P. Oxy. 1414 (AD 271-272), where arrangements for the collection of a tax known as the anabolikon are discussed by the council: there seems to be a lack of clarity concerning the process.

${ }^{16}$ 1. ll. 132-9. It is interesting that only two toparchies supply wheat.

${ }_{17}$ Noted by Skeat, P. Panop. Beatty p. xxv. For the daily ration of 2 sextarii, see P. Oxy. 1920. An entourage of such size moving through Egypt is hard to imagine.

${ }^{18}$ Duncan-Jones 1990, op. cit. (n. 7), 107-108. 
Two other main points are missing. First, we have little or no details on the extensive network of additional arrangements made for the provisioning of soldiers above and beyond the appointment of liturgists. As already mentioned, we have no information about quantity. Neither do we have much evidence for the time set aside for collection, place of storage, nor the transportation of the produce, which we know, from other sources, was an important factor falling under the remit of the city council. ${ }^{19}$ It is clear from elsewhere in the papyrus that ships had been requisitioned to carry supplies, and that some were requisitioned from outside the procuratorial district (suggesting a more centralised directive). We have no details of land transport, and this would have been a considerable task, involving the use of requisitioned animals in large number. We know from other evidence that animals and their owners were appointed to transport liturgies, both in the metropoleis and their nomes, and it is certain that these would have shouldered the burden of transport of these supplies in addition to their normal duties.

To broaden the context, earlier imperial visits to Egypt are fairly well represented in the papyri. We have evidence for Germanicus (AD 19), Hadrian (AD 130), and Septimius Severus and Caracalla (AD 199). ${ }^{20}$ We also have evidence for a projected visit to Egypt by Severus Alexander. ${ }^{21}$ In the light of Severus Alexander's projected visit (we have no evidence that it actually happened), we should remember that many imperial visits, although planned, never occurred, despite the necessary preparations being made. One can imagine the feelings of the local population in such an event. ${ }^{22}$ In all of this evidence we see similar features to the Panopolis texts. Liturgists are appointed to oversee the collection and delivery of provisions and animals to transport them. Existing bureaucratic structures are used, but additional commodities and liturgists were required, which must have stretched resources.

\footnotetext{
19 See, for example, P. Oxy. 1412 (c. AD 284), concerning the transport of military supplies.

${ }^{20}$ See F. Millar The Emperor in the Roman World (London 1992, 2nd ed.), 34 for details and references.

${ }^{21}$ See W. Clarysse and J.D. Thomas, 'A Projected Visit of Severus Alexander to Egypt', Ancient Society 8 (1977), 195-207 (= SB 12, 651); P. van Minnen and J.D. Sosin, 'Imperial Pork: Preparations for a Visit of Severus Alexander and Iulia Mammaea to Egypt', Ancient Society 27 (1996), 171-81.

${ }_{22}$ Millar 1992, op. cit. (n. 20), 32 cites the almost perennial plans of Tiberius to undertake journeys, which each year were aborted; cf. Suetonius, Tiberius 38 and Tacitus, Annals 1.47.3.
} 
As far as the prefect's conventus is concerned, details are more difficult. Like governors of other provinces, the prefect each year held a circuit court in pre-determined locations within the province, although the exact itinerary is unclear. $^{23}$ That there was a regular itinerary in itself suggests inequitable distribution of the burden. Whatever the pattern, we have evidence for visits to Arsinoe in the Fayum, Oxyrhynchos and Thebes, and know that the metropoleis of many nomes in the valley would have hosted the prefect. ${ }^{24}$ Just what use an official entourage, whether imperial or praefectural, would have made of existing state facilities on roads, mansiones, is not entirely clear, but in a well-known passage of the Life of Severus Alexander, the emperor posted up details of his stopping places in advance, including mansiones. ${ }^{25}$ From the Panopolis text, we see that provisioning the mansio at Panopolis was an important consideration for the procurator, and it therefore may be a stopping point on the emperor's itinerary. We do not have evidence, from Egypt at least, of any imposition of the emperor or prefect lodging with local elites. It is important to remember that our evidence gives only a snapshot, limited in time and place, of official visits covering entire provinces, and often in the case of imperial visits, more than one province. Despite this limitation, the picture afforded by the Egyptian evidence, therefore, may be more generally valid.

The commodities most frequently mentioned were destined for consumption by soldiers and horses of the units accompanying the emperors' or prefect's entourage, and in the case of the Panopolis text, some for the permanent garrisons; we have no evidence for what the requirements of the imperial party itself might have been, but they are unlikely to have been restricted to basic staples. Not all emperors were as considerate as Trajan, if we are to believe the Panegyric, where Pliny claims that he received the same supplies as others. ${ }^{26}$ This raises

${ }^{23}$ On the sequence of visits suggested by P. Oxy. 709 (c. AD 50), see Thomas 1982, op. cit. (n. 4), 15-29. Generally on the conventus, see G. Foti Talamanca, Ricerche sul Processo nell'Egitto greco-romano i: L'organizzazione del 'Conventus' del 'Praefectus Aegypti' (Milan 1974). For the governor's conventus elsewhere, see Millar 1992, op. cit. (n. 20), 28-31, primarily based on the evidence of Cicero, and A.J. Marshall, 'Governors on the Move', Phoenix 20 (1996), 231-246.

24 SB 9617 (AD 129); BGU 2211 (c. AD 192); P. Leit 12 = SB 10, 204 (AD 210-211); P. Petaus 47-7 (AD 185), P. Oxy. 3290 (AD 258-60). For Thebes, see I. Memnon 3; 8; $13 ; 15 ; 16 ; 24 ; 40 ; 57 ; 58$.

25 SHA, Severus Alexander 45.2, cited by Millar 1992, op. cit. (n. 20), 32.

26 Panegyricus 20, cited by Millar 1992, op. cit. (n. 20), 35. 
the perplexing problem of how these supplies of perhaps more luxurious commodities were raised. We know that animals for sacrifice were requisitioned for Diocletian's visit to Panopolis. In one of the papyri relating to the projected visit of Severus Alexander, 40 pigs, each weighing 50lbs, were to be supplied for the emperor's entourage. ${ }^{27}$ Collectors of meat in the Panopolis text must have gathered similar, if not larger, numbers. But emperors did not live on meat and bread alone; can anything be said about their wider requirements.

In short, no, but here, perhaps, something can be made of an important archive relating to a state official named Theophanes, who made an official journey from Hermopolis Magna in Middle Egypt to Antioch in Syria sometime in the late 320 's. ${ }^{28}$ The most striking feature of the accounts of Theophanes' expenditure (in cash) is the range of staple and luxury commodities he bought for his party over the course of his journey. For larger scale imperial and state processions, we have seen that large quantities of staple goods could be requisitioned in advance. Could it have been the case that members of the imperial familia had responsibility for buying locally available and fresh commodities during the course of the journey? If this is the case, the emperor's party (or that of a prefect) would have carried considerable quantities of cash, and it might very well have provided a welcome injection of money into the local economy. Emperors and governors were an attraction, not only for the spectacle, but also, obviously, for their judicial responsibilities. Huge numbers of petitions could be received, attracting many to the metropoleis who would not normally be there, which may have had some economic benefit. ${ }^{29}$

Finally, we come to the issue of cost: who paid for these commodities and their transport? Our evidence for requisition, especially that relating to transport (angaria) often obscures the probability that payment was forthcoming. The Panopolis text makes it clear that payment came from treasury funds, and this is supported by other evidence relating to requisition in Egypt, where it is not the inconvenience caused to local inhabitants by illegal requisitions that successive prefects are concerned

27 Van Minnen and Sosin 1996, op. cit. (n. 21).

28 See especially P. Ryl. 627-8.

29 On the large number of petitions received in the course of a prefect's visit, see P. Yale 61 (AD 209), which shows that in Arsinoe over a period of three days, the prefect Subatianus Aquila received 1804 petitions. 
about, but the fact that the Treasury is being defrauded. ${ }^{30}$ Commodities requisitioned at Panopolis, at least the 1,000 artabas of lentils and 10,000 sextarii of sour wine, were paid for from state funds (apo tôn tôे tameiou chrematôn). ${ }^{31}$ While we should certainly bear in mind the probability that such payment may not have been immediately forthcoming (there are examples in the papyri of liturgists waiting considerable periods for payment, sometimes years), and that state funds would not cover any necessary bribes to speed up proceedings, the long-term economic impact of visits might have been less than we would expect. However, we should not downplay the pressures in the short-term, the pressure to provide commodities, or for example, to bake bread for an entourage of hundreds or perhaps thousands at short notice, or the additional administrative pressures imposed on an already overstretched bureaucracy. It is likely also that any shortfalls in provisions were met from the liturgists' own pockets. What we are looking at is an imperial economy in operation: the cost of moving armies or officials around the empire is thought to have been small (for the state), but there could be significant short-term impact on local communities.

It is necessary now to draw some conclusions. First, what is clear from our evidence is that there was a significant local impact caused by irregular levies, a very real imposition for the individual, villages and metropoleis. What the Beatty text shows is that preparations for the visit of an emperor and his military entourage were massively intensive administrative exercises, largely devolved onto the local city councils and by them onto individuals. So the real impact was in terms of bureaucracy. It is difficult to believe that the burden was spread equally. Visits could last for some time - Hadrian was in Egypt for at least 8 months, Diocletian probably most of a year. The impact might have been felt at a local level, but this was also something hitting all parts of the empire in the course of imperial visits, a governor's adventus, or indeed any official or soldier travelling on state business. It was probably the most tangible and real imposition provincials felt, and this affords a perspective on the numerous provincial edicts designed to stop abuses in the systems of requisition. Second, any payments forthcoming for requisitioned goods or transport may have been paid for out of state funds (so there

${ }^{30}$ C.E.P. Adams, Land Transport in Roman Egypt: Economics and Administration in a Roman Province (Oxford 2007), ch. 7.

${ }^{31}$ P. Panop. Beatty 1. 1l. 244-8. 
was some notion of remuneration), but these funds were generated by tax payments. Although this means that some tax generated was reintroduced into the provincial economy, it probably did not feel like that to an individual. Payment was not always received immediately (and could be massively delayed), which could have severe consequences for individuals and force them into prolonged communication with local officials. Finally, we should not overlook the positive impact on local economies, but would these necessarily cancel out the negative?

We should not glibly gloss over these so-called 'irregular' impositions. I hope I have shown that they were more regular than usually thought, and they were arguably one of the most visible aspects of Roman rule and of the impact of the army on provinces. 
PART FOUR

THE IMPACT OF THE ROMAN IMPERIAL ARMY:

ITALY AND THE WEST 